\title{
Economic Consequences of Invasive Species in ornamental sector in Mediterranean Basin: An Application to Citrus Canker
}

\author{
Giuseppe Timpanaro, Arturo Urso, Vera Teresa Foti, Alessandro Scuderi \\ Dipartimento di Agricoltura, Alimentazione e Ambiente (Di3A), University of Catania, Italy
}

\begin{abstract}
Citrus Bacterial Cancer (CBC) is a severe phytopathy capable of compromising the economy, environment, and society in specific areas. To date, it is not present in the Mediterranean Basin. In essence, it could be a signal that European Phytosanitary Services have been able to control its spread, blocking import and marketing of fruits from risk areas or lacking the necessary phytosanitary requirements. However, in 2014 the EFSA launched the alarm on possible new forms of transmission of Xcc or Xanthomonas citri, the causative agent of the $\mathrm{CBC}$, represented by the marketing of ornamental Rutaceae and the flow of tourism, to and from risk areas. In this context, the research carries aim to assess direct and indirect damages that an invasion of the $\mathrm{CBC}$ could cause to the sector: its impacts at the micro-economic level fall on the production system and the consumer, while at the macro level on the entire community. The traceability of plant material during commercial operations is proposed as a possible solution, even if it becomes an accessory burden for businesses and consumers. In this sense, this research intends to offer some useful information to public and private, interested parties and to plan intervention policies.
\end{abstract}

\section{Keywords}

Xanthomonas citri, ornamental rutaceae, economic impact, damage assessment with income method, nurseries industry.

Timpanaro, G., Urso, A., Foti, V. T. and Scuderi, A. (2021) "Economic Consequences of Invasive Species in ornamental sector in Mediterranean Basin: An Application to Citrus Canker", AGRIS on-line Papers in Economics and Informatics, Vol. 13, No. 1, pp. 131-149. ISSN 1804-1930. DOI 10.7160/aol.2021.130110.

\section{Introduction}

Market globalization and climate change have increased the attention on the invasion of alien species and the spread of plant diseases, modifying the scenario of the defense of agricultural and forest plants. (Bradley et al., 2010; AA.VV., 2011; Chapman et al., 2017). The risks involve not only the agricultural, rural, forest, and landscape heritage but also biodiversity, ecosystem services, and public and private green areas (Timpanaro et al., 2014). The increasing costs deriving from current national emergencies, both in terms of direct damage to production and crops and in terms of expenses related to controls and eradication and containment measures, highlight the strategic role of defense and prevention that must be carried out by phytosanitary services, together with all the other international institutions interested in the plant protection. (European Food Safety Agency (EFSA); European and Mediterranean Plant Protection Organization (EPPO); EU Directorate
General for Health and Food Safety (SANTE), the main body of the European Commission operating within the framework of the International Plant Protection Convention (IPPC), Food and Agricultural Organization (FAO) and under the agreements signed in the World Trade Organization (WTO); US Department of Agriculture Animal and Plant Health Inspection Service (APHIS) (Timpanaro et al., 2020).

Food and Agricultural Organization identified six types of direct and indirect economic impacts of invasive species (FAO, 2001; Ameden, 2007): production, price and market effects, trade, food security and nutrition, human health and the environment, and financial impacts.

There are many contributions in the literature on the different aspects of the invasion. These are some of them:

- Prevention and control (Horan et al., 2002; Finnoff and Shogren, 2004; Finnoff et al., 2007; Panetta and Gooden, 2017). In this case, the two main strategies 
for the management of invasive species are mitigation (prevention with initiatives that aim to reduce the probability of an invasion occurring) and adaptation (control at any time during the invasion process and aim to reduce the extent of an attack rather than the likelihood of it happening) (Bellard et al., 2016);

- Application of rules and regulations (See and Dwight, 1984; Kambhu, 1990; Oh, 1995; Huang, 1996; Kadambe and Segerson, 1998; Genovesi et al., 2014). Researches show the optimal application of rules, the effect of taxation on company profits (Knowler and Barbier, 2005), the level of moral hazard of companies, which can pursue their interests at the expense of the community, trusting in the impossibility, for the latter, to verify the presence of willfulness or negligence (Shogren et al., 1990), costs of institutional monitoring. (Jenkins, 2002; Crowley et al., 2017);

- Effectiveness of different policy tools for invasive species, with the aim of trade regulation (Perrings, 2001; Costello and McAusland, 2003; McAusland and Costello, 2004; Horan and Lupi, 2005; Sheldon and Fitzpatrick, 2006). Potential policy instruments that may be used for prevention and control of invasive species including uniform technology standards, tradeable permits, fees and taxes as well as inspections. (Barbier et al., 2011; Jeschke et al., 2014);

- The ability to build an effective "bioeconomic modeling", capable of supporting political decisions. (Leung, 2002; Finnoff and Tschirhart, 2003; Shogren et al., 2006; Finnoff et al., 2006; Ameden et al., 2007; Finnoff and Tschirhart, 2003 and 2008), with an evolution from old approaches that provided for an intervention by the ex-post economist on the occurrence of the invasion to determine a "damage function" (Jardine and Sanchirico, 2018), to a modern ex-ante approach, according to which the economic system and ecosystem influence each other in preventing hypothetical damage from invasion.

In the latter case, the literature shows how the economic assessment of the impact of a hypothetical invasion is often demanding and inaccurate.
Economic impacts are classified into:

- primary (immediate impacts on affected farmers, with loss of income and economic and financial costs) and in secondary and tertiary (changes in consumer demand, relative prices of inputs, loss of biodiversity and other natural resources) (Evans, 2003);

- direct and indirect (Bigsby and Whyte, 2001), depending on whether the effects are due to the presence or dynamics of the alien species with effects on the community (such as the impairment of the main functions of the ecosystem; impacts on tourism and other sectors of the economy) or market (market access; consumer attitude towards a specific product; etc.).

Since international agreements on plant health and trade require that the assessment of the economic impact justify the regulation of a pest risk analysis (PRA), these are widespread in the literature. However, there are several qualitative assessments, which make the consequent regulatory decisions less effective, for example, whether or not to provide for a quarantine (Soliman et al., 2013; Anderson and Crosby, 2018; Bacher et al., 2018). Among the quantitative assessments, a comparative evaluation of the main techniques (partial budgeting, partial equilibrium analysis, input-output analysis, and computable general equilibrium analysis) is reported first by Born et al. (2005) and then in Soliman (2010). Then we must remember the empirical analyses carried out on citrus fruits in the USA due to the invasion of Huanglongbing (HLB), also known as Citrus Greening, capable of causing a reduction in production, in company profits, higher prices for consumers and a loss of jobs (Farnsworth et al., 2014; Moss et al., 2015); the quantification of direct damages over some time in which different types of invasions occurred in different territorial contexts (Williams et al., 2010; Andreu and Vilà, 2010; Hoffmann and Broadhurst, 2016; Atasoy and Çorbac1, 2018). Another perspective concerns the careful management of the limited financial resources available to support the impact of alien species, with a line of research that aims to identify the priority species also to guide the public reference regulation (legislation) (Courtois et al., 2018).

The last framework includes the intervention put in place to control bacterial citrus cancer (CBC), caused by two related but taxonomically distinct bacteria, named Xanthomonas citri pv. citri (synonym $X$. citri subsp. citri) and $X$. citri 
pv. aurantifolii (synonym $X$. fuscans subsp. aurantifolii). The first, which is the Asian citrus cancer agent, is by far the most prevalent in the world. CBC causes significant economic damage caused by the loss or non-marketability of the fruit (Acquaye et al., 2005). The disease is present in some areas of North and South America, Africa, India, West Asia, China, East Asia but has never been reported in Europe and the Mediterranean basin. Therefore, the two responsible bacteria are included in the A1 List of quarantine pathogens of the European and Mediterranean Plant Protection Organization (EPPO) (Caruso et al., 2017). In this case, the containment measures put in place to counter the invasion of $X c c$ through citrus fruits, destined for food consumption have been effective. However, in recent years there has been growing concern, in consideration of the development of the citrus fruit market with ornamental function (Timpanaro et al., 2020).

For these reasons, the Panel on Plant Health (PLH) of the European Food Safety Authority (EFSA), in the document "Scientific Opinion on the risk to plant health of Xanthomonas citri pv. Citri and Xanthomonas citri pv. Aurantifolii for the EU territory" (EFSA 2014) identified, among possible ways of entry of the bacterium into the Mediterranean basin, trade flows of ornamental Rutaceae species, considering that some of these are widely cultivated in the Mediterranean countries and which activate an essential economic and social function due to the high number of nurseries involved. Another possible way of spreading $X c c$ is, again, according to EFSA, represented by the movement of passengers and the tourist flow. In a globalized world and with the scarcity of resources available to national phytosanitary services, controlling trade and tourist flows is not an easily achievable goal. The import of citrus fruits and other species of Rutaceae other than the traditional species traditionally marketed (e.g., lemon, kumquat, and squid) for ornamental purposes represents, for nursery workers, an opportunity to differentiate the commercial offer and grow the results of a company. Over time it has led to a growth of exchanges of non-traditional species, also increasing the potential risk of introduction and spread of $X c c$ and other alien pathogens in the EU and the Mediterranean basin. On the other hand, the risk associated with the introduction of emerging diseases has prompted the extension of the international marketing ban to an increasing number of ornamental Rutaceae with a consequent compromise of benefits for consumers and profits for nurseries (Directive
2000/29/EC and subsequent amendments).

The economic issue is not indifferent, because a hypothetical accidental invasion of the pathogen through ornamental Rutaceae could compromise citrus growing for food purposes, above all located in Spain, Italy, Greece, Portugal, Cyprus, France, and Malta.

The present work is part of this framework, created to carry out a first economic assessment of the possible damage caused by an invasion of CBC in the Mediterranean Basin, based on official statistical documentation and an estimate based on the detection of a concrete case in an area with a high vocation for the production of ornamental citrus fruits. The methodological approach was chosen according to the regional scale and the availability of data and allowed to estimate the change in the profitability of companies, to meet a specific need expressed by different public and private stakeholders and to design a particular intervention program and policies.

\section{Materials and methods}

In order to extrapolate the areas invested in ornamental citrus fruits in the Mediterranean Basin, it was necessary to always use the EUROSTAT source and, in particular, to the "EUROSTAT Handbook for Anniversary Crop Statistics" (Regulation (EC), No. 543/2009, Commission Delegates Regulation (EU) 2015/1557 and ESS Agreement for the Annual Crop Statistics (Revision 2017).

Within the latter it was necessary to analyze the "FFS number", go back to "New Code", to the "Aggregate name" to the "Latin name and definition" and to the "Notes and explanation", to extrapolate the data of the most ornamental citrus fruits in cultivation.

The results of this discriminant analysis, although aware of its incompleteness, includes the following ornamental Rutaceae, species and varieties:

\begin{tabular}{|l|l|}
\hline LABEL & RUTACEOUS INCLUDED \\
\hline $\begin{array}{l}\text { Other small citrus fruits } \\
\text { (including hybrids) } \\
\text { n.e.c. }\end{array}$ & $\begin{array}{l}\text { Murraya paniculata, Koenigiu, } \\
\text { exotica, Microcitrus australasica; } \\
\text { Severinia buxifolia; } \text { Poncirus } \\
\text { trifoliata }\end{array}$ \\
\hline Other citrus fruits n.e.c. & $\begin{array}{l}\text { Citrus bergamia, } \text { C. Myrtifolia, C. } \\
\text { Hystrix, } \text { C. Fortunella crassifolia, } \\
\text { hindsii, japonica, } \text { margarita, } \\
\text { abovata, Limonia acidissima; } \\
\text { Lunasia (L. amara) }\end{array}$ \\
\hline Lemons and acid limes & $\begin{array}{l}\text { Limone meyer, Limetta romana, } \\
\text { Limetta mexicana }\end{array}$ \\
\hline Satsumas & Citrus Unshiu, var. owari \\
\hline
\end{tabular}


To assess the potential production of ornamental Rutaceae, starting from the statistical universe represented by the whole compared to "ornamental flowers and plants" in the EU, we used the EUROPHYT database. It is established and managed by the Directorate-General for Health and Food Safety of the European Commission, which deals with the interception for plant health reasons for parts of plants and plant products imported or distributed into the EU. EUROPHYT brings together all the results of the activity carried out by the various national phytosanitary services within a database, containing interceptions, trade within a non-EU plant species to provide essential support for the criteria of preventive measures. The main advantage of this source is that the data on the health risks of plants, deriving from the trade of plants and plant products carried out by professional operators, are updated and accurate. At the same time, the source has the limitation of not containing complete information relating to a possible introduction into the EU of harmful organisms through the commercial activity by non-professional operators (who enjoy specific derogations) or passengers - aware or unaware - of being vectors of alien species.

Assessed - with the limits just mentioned - the size of the sector in the territory, we proceeded with the evaluation of the production cost of the ornamental citrus seedling, to provide an economic evaluation based on the "producer price" (how to determine the income based on the "distribution" between the different figures of earners).

This assessment was carried out in Sicily, an area with the elective conditions, over the last twenty years, for the production of the ornamental citrus fruit. The commercial interest has arisen concerning the fact that most of the species of the genus Citrus and similar, have specific morphological and productive characteristics particularly responsive to the ornamental use, (for example the non-transience - winter of the leaves and the re-flowering). These products are increasingly destined to the amateur level in the gardens, in real gardens up to the city apartments.

For the determination of production costs, 10 nurseries were detected in Sicily, in particular, located between Catania (30\%), Messina (60\%) and Trapani $(10 \%)$ in coastal areas (Basile et al., 2000). The cost refers to a lemon seedling, with a degree of preparation at 36 months; the data were collected in 2018 and, in some cases, related to the last three years (2016-2018) and were elaborated with the following model widely used at European level:

$$
E p=\lfloor(F N V A+S)-(T+W+R+F+L+C)\rfloor
$$

where:

$E p=$ Economic profit $F N V A=$ Farm Net Value Added; $S=$ subsidies on investment; $T=$ Taxes on investment; $W=$ Wages and social security charges; $R=$ Rent paid for farm land and buildings and rental charges; $F=$ Family labor costs; $L=$ Costs of own land costs; $C=$ Costs of own capital costs.

The decision to focus on this species and on the 36-month staging was due to some reasons related to:

1. a typical Mediterranean citrus cultivation - the lemon - which boasts a history for ornamental purposes in pot that transcends the local and national context (in Tuscany, around 1960 began the trade of the lemon in pot that gave rise to the sector);

2. a considerable liveliness of the sector, with continuous and increasing adaptations in the product configuration;

3. an inflow of technological innovations of product and process in the production units, characterized by high levels of improvement of the activities;

4. competitive strategies of companies and business opportunities offered by a constantly evolving market, where production costs and availability to the consumer are the fundamental determinants of the company.

In this scenario, various problems emerge regarding:

- company organizational structure, as a result of the application of various management techniques and methods;

- use of common resources and more products, not only citrus but also on other species such as olive, laurel, etc.;

- obtaining a multitude of commercial products.

In the first and the second case, the companies were categorized into well-differentiated operative units designed to host ornamental plants in pots at different levels of development. The production 
process, related to each line (production cycle), takes place in a sequence of functional environments in space and time, different for the structures and productive means used, coherent with each phase of development of the pot plants.

In the third case - although found in the companies surveyed, a multitude of production lines concerning specific mercantile choices (which tend to extend the duration of the production process to more than 3 years) - it was decided to refer to the final layout in $21 \mathrm{~cm}$ diameter vase. In fact, from the investigations, the following articulation of the production lines emerged, as a result of which this choice was made:

\begin{tabular}{|l|c|}
\hline Size & $\mathbf{\%}$ \\
\hline Soilcells & $5-10 \%$ \\
\hline $16-18 \mathrm{~cm}$ pot & $5-10 \%$ \\
\hline $20-22 \mathrm{~cm}$ pot & $30-40 \%$ \\
\hline $24-25 \mathrm{~cm}$ pot & $20-30 \%$ \\
\hline $26-28 \mathrm{~cm}$ pot & $20-25 \%$ \\
\hline $35 \mathrm{~cm}$ pot & $0-5 \%$ \\
\hline
\end{tabular}

\section{Results and discussion}

\section{Scenario on the European ornamental plants and flowers sector}

The economic assessment of the impact of Xcc on ornamental citrus production is challenging to determine due to the shortcomings in the availability of official statistics divided by species, variety, and economic destination (commercial or ornamental).
The international data available are often referred to as the aggregate "ornamental flowers and plants," with or without the inclusion of "Christmas trees." Furthermore, since they are productions usually made by nurseries, some determinations lose significance, as we do not find strictly specialized structures in a single species or variety (Foti et al., 2017).

In Europe, the sector is widely diffused and decreasing in terms of production units $(-25 \%)$, as shown in Table 1. In 2013 (data made available in 2018), a total of 10.8 million companies are active in the production of flowers and ornamental plants.

The only country bucking the trend is Ireland $(+5 \%)$, while the traditional producing countries show evident contractions (Italy, $-42 \%$, Holland, $-18 \%$, France, $-17 \%$, Spain, $-11 \%$, etc.).

The restructuring process of the sector took place with a different trend in investments, which in the same period reached 220 thousand hectares, an increase of $20 \%$ (Table 2).

The restructuring process took place differently in different countries, with a consequent widening of the average size. Therefore, investments in Italy and Spain are expanding, recording respectively $+463 \%$ and $+57 \%$, in Portugal $(+28 \%)$, in the Netherlands $(+19 \%)$, in Poland $(+47 \%)$, etc. The contraction, however, has affected, to a lesser extent France $(-8 \%)$ and, to a greater extent Greece (-5\%). Furthermore, all countries present a different production specialization, with the varying incidence of "outdoor" and "under glass" cultivation, as shown in Figure 1.

\begin{tabular}{|c|c|c|c|c|c|}
\hline Area & $\begin{array}{c}2005 \\
\text { n. }\end{array}$ & $\begin{array}{c}2007 \\
\text { n. }\end{array}$ & $\begin{array}{c}2010 \\
\text { n. }\end{array}$ & $\begin{array}{c}2013 \\
\text { n. }\end{array}$ & Index \\
\hline Belgium & 51,540 & 48,010 & 42,850 & 37,760 & 73 \\
\hline Czech Republic & 42,250 & 39,400 & 22,860 & 26,250 & 62 \\
\hline Denmark & 51,680 & 44,620 & 41,360 & 38,280 & 74 \\
\hline Estonia & 27,750 & 23,340 & 19,610 & 19,190 & 69 \\
\hline Ireland & 132,670 & 128,240 & 139,890 & 139,600 & 105 \\
\hline Greece & 833,590 & 860,150 & 723,060 & 709,500 & 85 \\
\hline Spain & $1,079,420$ & $1,043,910$ & 989,800 & 965,000 & 89 \\
\hline Italy & $1,728,530$ & $1,679,440$ & $1,620,880$ & $1,010,330$ & 58 \\
\hline Cyprus & 45,170 & 40,120 & 38,860 & 35,380 & 78 \\
\hline
\end{tabular}

Source: EUROSTAT

Table 1. Flowers and ornamental plants: total number of farms and areas in Europe (to be continued). 


\begin{tabular}{|c|c|c|c|c|c|}
\hline Area & $\begin{array}{c}2005 \\
\text { n. }\end{array}$ & $\begin{array}{c}2007 \\
\text { n. }\end{array}$ & $\begin{array}{c}2010 \\
\text { n. }\end{array}$ & $\begin{array}{c}2013 \\
\text { n. }\end{array}$ & Index \\
\hline Latvia & 128,670 & 107,750 & 83,390 & 81,800 & 64 \\
\hline Luxembourg & 2,450 & 2,300 & 2,200 & 2,080 & 85 \\
\hline Hungary & 714,790 & 626,320 & 576,810 & 491,330 & 69 \\
\hline Netherlands & 81,830 & 76,740 & 72,320 & 67,480 & 82 \\
\hline Austria & 170,640 & 165,420 & 150,170 & 140,430 & 82 \\
\hline Poland & $2,476,470$ & $2,390,960$ & $1,506,620$ & $1,429,010$ & 58 \\
\hline Portugal & 323,920 & 275,080 & 305,270 & 264,420 & 82 \\
\hline Slovakia & 68,490 & 68,990 & 24,460 & 23,570 & 34 \\
\hline Finland & 70,620 & 68,230 & 63,870 & 54,400 & 77 \\
\hline Sweden & 75,810 & 72,610 & 71,090 & 67,150 & 89 \\
\hline United Kingdom & 286,750 & 226,660 & 185,200 & 183,700 & 64 \\
\hline Iceland & : & : & 2,590 & : & \\
\hline Norway & 53,000 & 49,940 & 46,620 & 43,730 & 83 \\
\hline Switzerland & 63,630 & 61,760 & 59,070 & : & 93 \\
\hline Montenegro & : & : & 48,870 & : & \\
\hline
\end{tabular}

Source: EUROSTAT

Table 1. Flowers and ornamental plants: total number of farms and areas in Europe (continuation).

\begin{tabular}{|c|c|c|c|c|c|c|c|c|c|c|c|c|c|}
\hline Member state & \multicolumn{3}{|c|}{2007} & \multicolumn{3}{|c|}{2010} & \multicolumn{3}{|c|}{2013} & \multicolumn{3}{|c|}{2016} & Index \\
\hline Germany & 20.9 & 7 & 27.9 & 20.9 & 8.4 & 29.3 & 20.7 & 7.7 & 28.4 & 19.3 & 7.3 & 26.6 & 95 \\
\hline Spain & 15.6 & 3 & 18.6 & 19.2 & 6.7 & 25.9 & 20 & 7 & 27 & 22.8 & 6.4 & 29.2 & 157 \\
\hline Netherlands & 14.9 & 27.5 & 42.4 & 17.4 & 26.2 & 43.6 & 17.5 & 26.2 & 43.7 & 17.8 & 32.6 & 50.4 & 119 \\
\hline France & 18.3 & 7.9 & 26.2 & 18.3 & 8.1 & 26.4 & 15 & 9 & 24 & 15.1 & 8.9 & 24 & 92 \\
\hline Hungary & 10.6 & 0.4 & 11 & 11.4 & 0.5 & 11.9 & 7.5 & 0.5 & 8 & 6.3 & 0.5 & 6.8 & 62 \\
\hline United Kingdom & 7 & 6 & 13 & 6 & 5 & 11 & 6 & 6 & 12 & 6 & 6 & 12 & 92 \\
\hline Bulgaria & 0 & 3.6 & 3.6 & 2.1 & 0 & 2.1 & 1.9 & 0 & 1.9 & 2.2 & 0 & 2.2 & 61 \\
\hline Czech Republic & 0 & 1.9 & 1.9 & 0.4 & 1.3 & 1.7 & 1.7 & 0.3 & 2 & 2.2 & 0.3 & 2.5 & 132 \\
\hline Portugal & 1.1 & 1.8 & 2.9 & 1 & 2.1 & 3.1 & 0.3 & 2.9 & 3.2 & 0.2 & 3.5 & 3.7 & 128 \\
\hline Lithuania & 0.2 & 0.1 & 0.3 & 0.4 & 0.1 & 0.5 & 0.4 & 0.1 & 0.5 & 0.4 & 0.2 & 0.6 & 200 \\
\hline Slovenia & 0.2 & 0.2 & 0.4 & 0.4 & 0.1 & 0.5 & 0.3 & 0.1 & 0.4 & 0.3 & 0.1 & 0.4 & 100 \\
\hline Slovakia & 0 & 0.3 & 0.3 & 0.4 & 0.2 & 0.6 & 0.3 & 0.2 & 0.5 & 0.4 & 0.1 & 0.5 & 167 \\
\hline Croatia & 0.2 & 0.1 & 0.3 & 0.4 & 0.3 & 0.7 & 0.2 & 0.3 & 0.5 & 0.3 & 0.3 & 0.6 & 200 \\
\hline Romania & 0.7 & 0.3 & 1 & 0.8 & 0.2 & 1 & 0.5 & 0.5 & 1 & 0.3 & 0.5 & 0.8 & 80 \\
\hline Luxembourg & 0.1 & 0 & 0.1 & 0.1 & 0 & 0.1 & 0.1 & 0 & 0.1 & 0.1 & 0 & 0.1 & 100 \\
\hline
\end{tabular}

Source: EUROSTAT and DGAGRI-G2, Working Document on Flowers and Ornamental Plants, Statistics 2006-2016

Table 2: Flowers and ornamental plants: 1,000 hectares and areas in Europe (to be continued). 


\begin{tabular}{|c|c|c|c|c|c|c|c|c|c|c|c|c|c|}
\hline Member state & \multicolumn{3}{|c|}{2007} & \multicolumn{3}{|c|}{2010} & \multicolumn{3}{|c|}{2013} & \multicolumn{3}{|c|}{2016} & Index \\
\hline Malta & 0 & 0 & 0 & 0 & 0.1 & 0.1 & 0 & 0 & 0 & 0 & 0 & 0 & - \\
\hline Denmark & 0 & 2.3 & 2.3 & 0 & 1.9 & 1.9 & 1.2 & 0.3 & 1.5 & 2 & 0.3 & 2.3 & 100 \\
\hline Estonia & 0.4 & 0.1 & 0.5 & 0.5 & 0 & 0.5 & 0.2 & 0 & 0.2 & 0.2 & 0 & 0.2 & 40 \\
\hline Ireland & 0 & 0 & 0 & 0.2 & 0.1 & 0.3 & 0.3 & 0.2 & 0.5 & 0.3 & 0.2 & 0.5 & - \\
\hline Cyprus & 0.1 & 0.2 & 0.3 & 0.1 & 0.1 & 0.2 & 0 & 0.2 & 0.2 & 0 & 0.1 & 0.1 & 33 \\
\hline Latvia & 0 & 0.1 & 0.1 & 0 & 0.1 & 0.1 & 0 & 0.1 & 0.1 & 0.3 & 0.1 & 0.4 & 400 \\
\hline Finland & 0 & 0 & 0 & 0 & 0 & 0 & 0 & 0 & 0 & 0 & 0 & 0 & - \\
\hline Sweden & 0.4 & 0.5 & 0.9 & 0.4 & 0.4 & 0.8 & 1.8 & 0.2 & 2 & 0.5 & 0.2 & 0.7 & 78 \\
\hline
\end{tabular}

Source: EUROSTAT and DGAGRI-G2, Working Document on Flowers and Ornamental Plants, Statistics 2006-2016

Table 2: Flowers and ornamental plants: 1,000 hectares and areas in Europe (continuation).

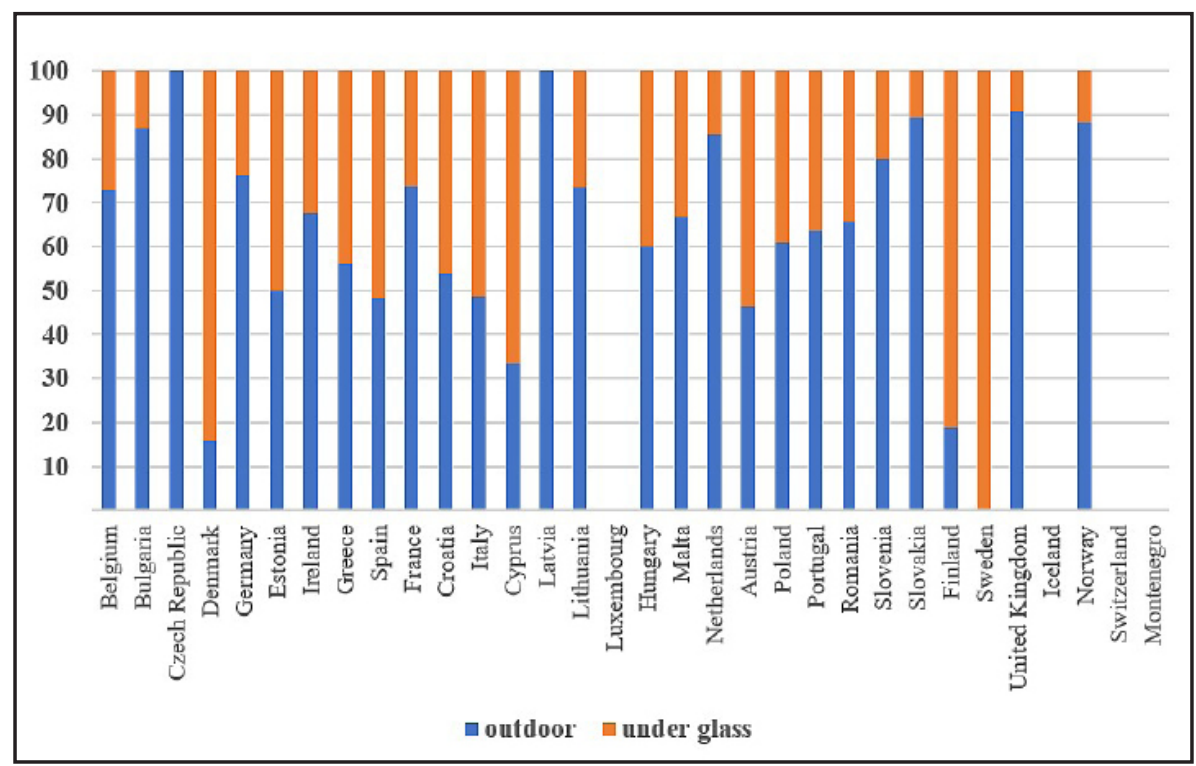

Source: EUROSTAT

Figure 1: Distinction of flower and ornamental plant in Europe by production method.

In general, at higher latitudes, in the countries of Northern Europe, there is an increase in the rate of cultivation "under glass," to preserve the characteristics of the value, especially in the production of flowers (Timpanaro et al., 2013; Butti Al Shamsi et al., 2018).

For this reason, it was necessary to adopt a specific discriminant analysis for customs tariff codes, starting from the same EUROSTAT statistics, to evaluate the most probable economic value of the impact of $X c c$.

A picture of the production generated by the aggregate "ornamental plants and flowers (including the Christmas tree)" is visible in Table 3, which highlights the evolution of the output of the sector in the last decade.

From these data emerges a fluctuating trend in the sector over the entire period analyzed and the role of "key actors" in some countries. In fact, in the EU - in its "current composition" - the sector realizes production of 8,060 million euros, in which contribute in order of importance Netherlands (with $30 \%$ of this value), Germany and Italy (14\% each), France (12\%), Spain (about 9\%), Denmark (about 5\%) and Switzerland (about 4\%).

In these evaluations, a significant role is played by "flowers" as traditional production in specific territories. 




Source: EUROSTAT, Bruxelles (2018).

Table 3. Economic accounts for "Ornamental plants and flowers (including Christmas trees)" - values at current prices (Production value at producer price) (Mln EURO). 
2. The spread of $X c c$ in the world and possible implications for ornamental Rutaceae in the Mediterranean Basin

EPPO has signaled the presence of Xcc in Asia, Africa, America, and recently in Oceania (Western Australia; Fiji; Guam; Marshall Islands; Micronesia), although with diversified importance in the various environments (Figure 2). In the various environments, Xcc is present in a diversified way (Present, no details; Present, widespread; Present, restricted distribution; Present, few occurrences), transient (Transient, under eradication) or absent (Absent, confirmed by survey; Absent, invalid record; Absent, pest eradicated).

The annexes of Directive 2000/29/EC (and subsequent amendments and additions) have been modified over time to include some random agents of $\mathrm{CBC}$ to protect the Mediterranean Basin. In particular, the directive intervenes in the prevention of many species of the genus Citrus, Fortunella, Poncirus, Murraya könig (in fact, since subject to Diasphorina citri Kuway) and related hybrids (subject to contamination), except fruits and seeds.

According to EUROPHYT, interceptions in over $73 \%$ of cases concern some countries, such as Bangladesh, Pakistan, China, India, Vietnam and Uruguay and, in particular, some species of ornamental Rutaceae (Citrus aurantifolia, Citrus latifolia, Citrus limon, Citrus hystrix, and Citrus SPP) and the mainly involve propagation material (scions and cuttings), often without the necessary plant passport (Table 4).



Source: EPPO Global Database, 2020

Figure 2: Spread of Xcc worldwide (EPPO, 2020).

\begin{tabular}{|c|c|c|c|c|c|c|c|c|c|c|c|c|c|c|}
\hline & $\begin{array}{c}\text { Citrus } \\
\text { aurantifolia }\end{array}$ & $\begin{array}{c}\text { Citrus } \\
\text { latifolia }\end{array}$ & $\begin{array}{l}\text { Citrus } \\
\text { limon }\end{array}$ & $\begin{array}{c}\text { Citrus } \\
\text { limettoides }\end{array}$ & $\begin{array}{c}\text { Citrus } \\
\text { paradisi }\end{array}$ & $\begin{array}{l}\text { Citrus } \\
\text { reticulata }\end{array}$ & $\begin{array}{c}\text { Citrus } \\
\text { Maxima }\end{array}$ & $\begin{array}{l}\text { Citrus } \\
\text { hystrix }\end{array}$ & $\begin{array}{l}\text { Citrus } \\
\text { sinensis }\end{array}$ & $\begin{array}{c}\text { Citrus } \\
\text { amblycarpa }\end{array}$ & Citroncirus & $\begin{array}{l}\text { Citrus } \\
\text { SP. }\end{array}$ & $\begin{array}{c}\text { Non- } \\
\text { citrus } \\
\text { species }\end{array}$ & Total \\
\hline Bangladesh & 11 & 9 & 4 & - & - & - & - & - & 1 & - & - & 14 & 3 & 42 \\
\hline Pakistan & 3 & 10 & - & 1 & 1 & 4 & - & - & - & - & - & 4 & 1 & 24 \\
\hline China & - & - & - & - & 2 & - & 14 & - & - & - & - & - & - & 16 \\
\hline India & 4 & - & 4 & - & - & - & - & - & - & - & - & 3 & 2 & 13 \\
\hline Vietnam & - & 4 & - & - & - & - & - & 5 & - & - & - & 1 & - & 10 \\
\hline Uruguay & - & - & 6 & - & - & 1 & - & - & 5 & - & - & - & - & 12 \\
\hline Thailand & - & - & - & - & - & - & - & 2 & - & - & - & 4 & 1 & 7 \\
\hline Argentina & - & - & 6 & - & - & 1 & - & - & 2 & - & - & - & - & 9 \\
\hline Malaysia & - & 1 & - & - & - & - & - & 2 & - & - & - & 3 & - & 6 \\
\hline Indonesia & - & - & 1 & - & - & - & - & 6 & - & 1 & - & - & - & 8 \\
\hline Bolivia & - & - & 4 & - & - & - & - & - & - & - & - & - & - & 4 \\
\hline Brazil & - & 5 & - & - & - & - & - & - & - & - & - & - & - & 5 \\
\hline $\begin{array}{l}\text { United Arab } \\
\text { Emirates }\end{array}$ & - & - & - & - & - & 1 & - & - & - & - & - & - & 1 & 2 \\
\hline \multirow[t]{2}{*}{ Others } & & & & & & & & & & & 3 & & & 3 \\
\hline & & & & & & & & & & & & & & 161 \\
\hline
\end{tabular}

Source: Our elaboration on Euphidra data.

Table 4: Interceptions of Xcc by country and species (2019). 
The process of extrapolation of the data on ornamental citrus fruits has revealed a spread in the Mediterranean basin of more than 4.4 thousand hectares invested in these Rutaceae and an intense polarization in some countries (Italy, France, Spain, Turkey, and Greece) (Table 5).

This assessment is based on the areas subject to the phytosanitary provisions in force in the EU since 14 December 2019 (EUROPHYT), mainly derived from professional nurserymen, i.e., operators who, according to the current regulation (EU) 2016/2031, are legally responsible for one or more operations from the plant, reproduction, production, including cultivation, multiplication and maintenance, introduction, movement within the Union territory and out of the Union territory, made available on the market; storage, collection, shipping, and processing. They must also register with an Official Register of Professional Operators (RUOP) and guarantee an effective traceability system.

In reality, the production potential of ornamental Rutaceae is higher if we also consider the large amount of propagation material that ends up in the circuit of non-professional Operators or home gardeners, in travelers' luggage or the event that the movement of plants or parts of plants it is directly addressed to an end-user. In essence, anyone can purchase the product on electronic sites or other means of sales through distance contracts, for which the same EU Reg. 2016/2031 maintains specific exemptions (articles 75; 81).

The world of non-professional operators is very large and varied (retail bedding and nursery stock; greenhouse/annuals; retail lawn and garden products; retail general merchandise; retail landscape materials; nursery container and field; landscape services/build; landscape architecture/ design; wholesale bedding and nursery stock; retail garden equipment; wholesale landscape materials; retail florist and florist supplies; retail food and beverage; lawn and garden equipment; wholesale lawn and garden products; wholesale florist and florist supplies; wholesale garden equipment), and so is that of electronic commerce (multi-channel, electronic, and direct distribution for final consumption, EU Reg. 2017/625 identifies two elements as a defense against invasion or the traceability and control of the supply chain in a physical location. However, the consumer can connect directly to platforms, not of production but of intermediation, which offers products of all kinds, also of evident foreign, community,

\begin{tabular}{|c|c|c|c|c|c|}
\hline Country & $\begin{array}{l}\text { Other small citrus } \\
\text { fruits (including } \\
\text { hybrids) n.e.c. } \\
\text { (a) }\end{array}$ & $\begin{array}{c}\text { Other citrus fruits } \\
\text { n.e.c. (b) }\end{array}$ & $\begin{array}{l}\text { Lemons and acid } \\
\text { limes } \\
\text { (c) }\end{array}$ & $\begin{array}{l}\text { Satsumas } \\
\text { (d) }\end{array}$ & $\begin{array}{l}\text { Our evaluationtotal } \\
\qquad \% \mathrm{a}+\mathrm{b}+\mathrm{c}+\mathrm{d})\end{array}$ \\
\hline Greece & 0.00 & 0.93 & 3.26 & 0.00 & 0.177 \\
\hline Spain & 28.87 & 1.09 & 43.08 & 8.49 & 0.821 \\
\hline France & 0.38 & 0.00 & 0.94 & 0.00 & 0.782 \\
\hline Italy & 0.00 & 1.55 & 25.61 & 0.00 & 1.436 \\
\hline Cyprus & 1.06 & 0.04 & 0.47 & 0.00 & 0.056 \\
\hline Malta & 0.00 & 0.00 & 0.00 & 0.00 & 0.00 \\
\hline Portugal & 1.49 & 0.00 & 1.00 & 0.17 & 0.266 \\
\hline Montenegro & 0.15 & 0.00 & 0.00 & 0.00 & 0.015 \\
\hline Albania & 0.00 & 0.00 & 0.05 & 0.01 & 0.006 \\
\hline Bosnia and Herzegovina & 0.00 & 0.00 & 0.00 & 0.00 & 0.000 \\
\hline Turkey & 23.00 & 0.01 & 32.00 & 24.00 & 0.791 \\
\hline Total (c) & 23.15 & 0.01 & 32.05 & 24.01 & 0.812 \\
\hline Total (a) /(c) & 57.05 & 3.62 & 106.47 & 32.67 & 4.398 \\
\hline
\end{tabular}

Source: EUROSTAT and our elaborations for the extrapolation of the ornamental citrus data from the total item relating to the citrus genus

Table 5. Estimation of the area invested in ornamental citrus fruits in the EU, with particular reference to some countries of the Mediterranean Basin 2018 (1,000 ha). 
or non-EU origin). According to EU Reg. 2019/2072, these end-users should report if they find the presence of Xcc since the latter is included in the list of quarantine pests relevant for the Union, in particular in "Part A - Harmful organisms the existence of which is not known in the territory of the Union".

\section{Economic assessment of the damage from $\mathrm{Xcc}$ invasion}

\section{Direct costs determination at the micro-level}

Based on the indicated methodology, we extrapolated a determination of the standard production costs of an ornamental Rutaceae seedling in a representative area (Allegra and Zarbà, 2015).

Overall, an average production cost of 4.528 Euro/seedling of Citrus limon lunario emerged on Citrus wolkameriana, to which the materials (35\%) the works and services (about 40\%) and the quotas and the other contributors in a different way attribution (about 28\%), as shown in Table 6.

\begin{tabular}{|c|c|c|}
\hline Indication & EURO/plant & $\%$ \\
\hline Matherials & 1.466 & 32.40 \\
\hline - propagation matherials & 0.037 & 0.83 \\
\hline - single-use pots & 0.043 & 0.96 \\
\hline - pots for sale & 0.492 & 10.87 \\
\hline - soil & 0.171 & 3.77 \\
\hline - plant-protection products & 0.149 & 3.30 \\
\hline - fertlizers & 0.262 & 5.78 \\
\hline - other products & 0.312 & 6.89 \\
\hline Labour and services & 1.806 & 39.90 \\
\hline - abour & 1.608 & 35.51 \\
\hline - phytosanitary treatments & 0.159 & 3.52 \\
\hline - internal handlings & 0.038 & 0.85 \\
\hline Other costs & 1.256 & 27.70 \\
\hline - fees & 0.363 & 8.01 \\
\hline - department manager & 0.121 & 2.67 \\
\hline - irrigation equipment & 0.073 & 1.60 \\
\hline $\begin{array}{l}\text { - warehouses for machines } \\
\text { and tools }\end{array}$ & 0.052 & 1.14 \\
\hline - screen house & 0.212 & 4.68 \\
\hline - capital interests & 0.101 & 2.23 \\
\hline - advance rate $(1 \%)$ & 0.042 & 0.92 \\
\hline - salaries & 0.121 & 2.67 \\
\hline - taxes & 0.030 & 0.66 \\
\hline - transactional costs & 0.022 & 0.49 \\
\hline - direction & 0.121 & 2.67 \\
\hline Total costs per plant & 4.528 & 100.00 \\
\hline
\end{tabular}

Source: Our elaboration on data results from direct survey

Table 6: Average unit production cost of an ornamental lemon plant in Sicily (2018).
The average uses of production factors (rootstocks and marzas for varieties, pots, etc.) influence the cost of materials. The use in each department weighs heavily on the job cost, especially in grafting operations. Lastly, the costs of management, administration and surveillance and the management of the "screen house" intercept the highest rates ("screen house" is the structure for the production of certified cuttings used in the constitution of the grafts of the Lunario cultivars. the regional phytosanitary services also control it).

The composition of costs during production (36 months), shows (Figure 3) the weight of reproduction operations (4\%) and nest/growth (54\%), compared to the set-up activity (12 months) of plants $(41 \%)$. These data lead some nurserymen to acquire outside the seedlings directly by other nurserymen traditionally active in the regional, extra-regional, and overseas flower-growing areas. This practice generates some safety about the spread of Xcc since, in the standard, these structures are activated with official recognition phytosanitary authorities competent in the matter.

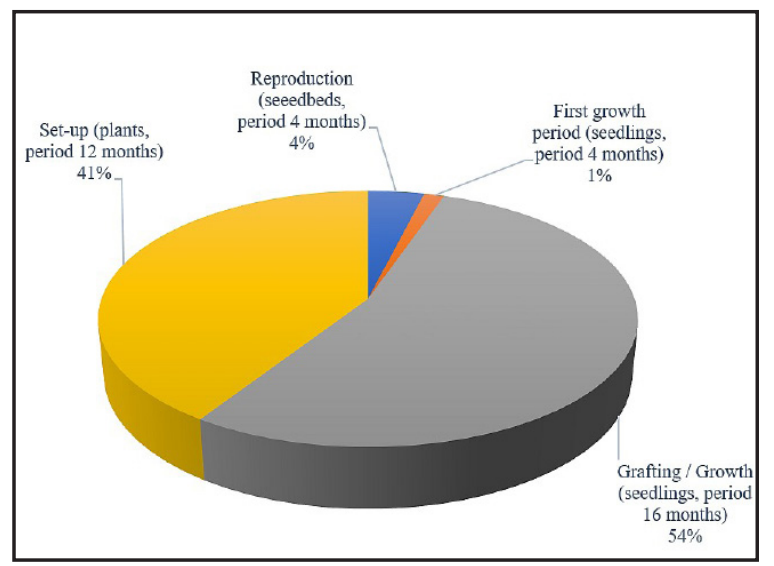

Source: Our elaboration on data results from direct survey

Figure 3: Structure of the average production cost of an ornamental citrus plant in Sicily by vegetative phase (36 months).

For the construction of a scenario of a possible economic impact of $X c c$ in the Mediterranean basin, it was necessary to integrate the official statistics using the FAO data in addition to the EUROSTAT data (Table 7).

In this case, the data are no longer referred only to ornamental citrus fruit but to the entire "citrus" genus, to have a clear - though apocalyptic - scenario of invasion and infection extended to the whole of commercial citrus production. 


\begin{tabular}{lrrr}
\hline \multirow{2}{*}{ Countries } & \multicolumn{2}{c}{2016} & \multicolumn{1}{c}{2014} \\
\cline { 2 - 3 } & \multicolumn{1}{c}{ ha } & \multicolumn{1}{c}{$\mathrm{t}$} & \multicolumn{1}{c}{ EUR } \\
\hline Albania & $1,547.00$ & $41,051.00$ & $937,580.78$ \\
Algeria & $58,663.00$ & $1,201,847.00$ & $930,489,084.36$ \\
Bosnia and Herzegovina & 281.00 & 210.00 & 0.01 \\
Croatia & $2,192.00$ & $53,257.00$ & $14,724,781.93$ \\
Cyprus & $2,166.00$ & $79,047.00$ & $16,586,384.79$ \\
Egypt & $196,273.00$ & $4,806,393.00$ & $849,776,201.81$ \\
France & $4,339.00$ & $51,869.00$ & $10,970,264.05$ \\
Greece & $54,450.00$ & $1,099,642.00$ & $268,297,445.92$ \\
Israel & $17,529.00$ & $318,000.00$ & $201,559,926.88$ \\
Italy & $146,691.00$ & $2,561,555.00$ & $1,599,059,659.38$ \\
Jordan & $5,976.00$ & $115,536.00$ & $33,177,592.77$ \\
Lebanon & $12,355.00$ & $299,750.00$ & $121,701,784.71$ \\
Libya & $8,009.00$ & $81,263.00$ & $17,187,078.36$ \\
Malta & 126.00 & $1,730.00$ & 1.20 \\
Montenegro & $1,099.00$ & $12,818.00$ & $2,710,999.72$ \\
Morocco & $123,112.00$ & $2,042,273.00$ & $533,027,952.66$ \\
Occupied Palestinian Territory & $1,208.00$ & $20,441.00$ & $371,398.48$ \\
Portugal & $20,336.00$ & $354,065.00$ & $107,802,589.78$ \\
Réunion & 112.00 & $1,844.00$ & $390,004.95$ \\
Spain & $361,477.00$ & $6,950,952.00$ & $1,220,938,644.42$ \\
Syrian Arab Republic & $44,748.00$ & $1,204,286.00$ & $254,705,805.19$ \\
Tunisia & $35,279.00$ & $377,086.00$ & $64,596,925.01$ \\
Turkey & $129,488.00$ & $4,039,887.00$ & $288,714,062.55$ \\
Total & $\mathbf{1 , 2 2 7 , 4 5 6 . 0 0}$ & $\mathbf{2 5 , 7 1 4 , 8 0 2 . 0 0}$ & $\mathbf{6 , 5 4 6 , 2 2 6 , 1 6 9 . 7 4}$ \\
\hline
\end{tabular}

Source: Food and Agriculture Organization of the United Nations (FAO)

Table 7: Some indicators on citrus fruits in the countries of the Mediterranean Basin (2018).

\section{Economic dimension of Rutaceae production in the Mediterranean Basin}

What emerges is the importance of the citrus genus for this area in which - even if differentiated by country - it amounts to over 1.227 million hectares and almost 26 million tons, with a production of over 6.5 billion euros.

Table 7 shows the weight of each country and, in particular, Italy (almost 1.6 billion euros), Spain (over 1.2 billion euros), France (about 11 million euros), and Turkey (288 billion euros).

For the determination of the economic impact of $X c c$, it was then proceeded by retrieving in literature the possible damages caused by a possible infection and defining some hypotheses concerning, for example, a possible protection protocol.

To this end, we have to consider that the spread of Xcc can - according to a pessimistic approach
- have a macroeconomic impact on the entire sector, putting at risk the estimated production value for ornamental citrus and in the most extreme cases the value of the industry of commercial citrus fruits, with considerable economic impact (Table 8).

\begin{tabular}{l|c|c}
\hline Products & Source & Value Mln $€$ \\
\hline Ornamental citrus & Our assessment & $2,424.35$ \\
Commercial citrus & FAO & $6,546.23$ \\
\hline
\end{tabular}

Source: Our assessment and FAO

Table 8: Production of ornamental and commercial citrus fruits in the Mediterranean basin potentially threatened by the invasion of Xcc (2018).

At the microeconomic level (nursery farm), on the other hand, we proceeded with an income approach. It is a generalization that is linked to scenarios of hypothetical lower profitability obtainable from the sector as a consequence of the advent of $X c \mathrm{c}$ and that in no way does not take into account indirect impacts (induced), social 
costs (supported by the system that should be called upon to deal with a phytosanitary problem) and the reduced possibility of use and recreation by the consumer that is difficult to determine in the absence of systematic data.

To that end, in Sicily, according to the data of the Regional Councilor for Agricultural and Food Resources, it is possible to hypothesis within the nurseries a density varying between 45 thousand and 60 thousand plants/hectare. Not only that, but the survey conducted in Sicily has allowed highlighting the endogenous characteristics of the main types of companies with ornamental citrus nursery, and the entrepreneurial approach eventually followed (different between micro-very small and medium-large nursery). The reactions of nurseries to Xcc can be very different, from total indifference to extremely particular forms of prevention (Scuderi and Sturiale, 2016). Therefore, we analyzed two company balances (referring to 2018), so it is possible to quantify the probable damage in:

1. Lack of income, resulting in irreversible damage for loss of plants;

2. Increase in production costs as a result of adopting more frequent prevention techniques (for example defined in a sort of guidelines, which include defense, control, surveillance, removal of plant parts, etc.).

The first analysis is based on the income approach. It provides for the determination of the capitalization or yield rate necessary to update the income that the ornamental citrus plant can provide. This test considering alternative investments, however similar, for security and economic duration was calculated by mediating the yield of long-term government securities for the year $2018(\mathrm{r}=2.5 \%)$. The test so defined was corrected, increasing or decreasing according to the type of company (micro-very small nursery vs. medium-large nursery), to take into account the different riskiness between investments and the various function performed by the rate of return compared to the function of the capitalization rate. Ultimately, the essay tends to decrease in case of security and ease of operation of the company, greater security of income perception, more excellent attractiveness of the fund, more "comfortable" offered by the funds. It happens in reality in the larger and more densely invested nurseries, compared to the micro-nurseries for which a higher rate has been attributed.

For the second analysis, on the other hand, in the literature, the assessment of the economic impacts on companies deriving from the spread of plant diseases is carried out with quantitative methods, such as partial balance analysis, partial balance models, input-output analysis and general equilibrium models. The choice of the most appropriate model depends on the objective of the report, the regional scale, and the availability of data.

\section{Assessment of the economic impact in case of invasion}

In the present work, we carried out the assessment of the economic impact and the estimate of the possible damages caused by Xcc using the partial balance approach, which made it possible to estimate the profitability variation of ornamental citrus nurseries as a result of the application of potential prevention and action guidelines (Danzì et al., 2020).

The irreversible damage was estimated according to the procedure of lost income, assuming a period following the eradication of the plants and such as to allow the reimplantation and restoration of production conditions, equal to 5 years.

Therefore, transitory income obtained from the difference between the ex-ante income and the ex-post income of the possible infection was calculated.

Therefore, the discounting and the sum of the flow of such annual income related to the period necessary for the restoration of the ex-ante conditions, in addition to the cost of replanting, was then passed.

Table 9 shows the amount of damage per plant and type of nursery, assuming a constant capitalization rate $(r=2.5 \%)$, equal to 14.1 EURO /plant for the micro-very small farm and 12.1 EURO /plant for the medium-large company.

About the economic aspect of a possible prevention protocol, the first type suffers more damage due to higher gross profitability composed by non-binding measures and stricter than the provisions of the phytosanitary legislation and the rules on conditionality, designed to reduce the risk of spreading the disease.

The planned interventions concern:

- $\quad$ surveillance and removal of plants or parts of plants;

- careful management of the defense;

- $\quad$ putting in place prevention systems.

The analysis of production costs following 


\begin{tabular}{lcc}
\hline Labels & $\begin{array}{c}\text { Small-micro } \\
\text { nursery }\end{array}$ & $\begin{array}{c}\text { Medium-large } \\
\text { nursery }\end{array}$ \\
\hline Economic duration (max) & 5 years & 5 years \\
Age of the plants & 3 years & 3 years \\
Periods (y) of lack of income & 2 & 2 \\
Average price at nursery per ornamental plant $(€)$ & 11.5 & 60,000 \\
Average production/ha & 45,000 & $630,000.00$ \\
Failed revenue $(€)$ & $517,500.00$ & 4.2 \\
Failed costs (fertilization, treatements, control, ecc.): $40 \%$ of price & 4.2 & 6.3 \\
Lack of annual income, $€ /$ plant & 7.3 & 12.1 \\
Impact on n. 1 ornamental lemon plant & 14.1 & $(q n-1)$ \\
\hline
\end{tabular}

Table 9. Evaluation of the economic impact of the introduction of Xcc according to an income approach (2018).

\begin{tabular}{l|c|c|c|c|c|c|c|c}
\hline \multirow{2}{*}{ Impact Level } & \multicolumn{2}{|c|}{ Matherials and costs } & \multicolumn{2}{c|}{ Labour and services } & \multicolumn{2}{c|}{ Fees and other costs } & \multicolumn{3}{c}{ Total } \\
\cline { 2 - 9 } & $€ /$ plant & Index & $€ /$ plant & Index & $€ /$ plant & Index & $€ /$ plant & Index \\
\hline O & 1.466 & $\mathbf{1 0 0}$ & 1.806 & $\mathbf{1 0 0}$ & 1.256 & $\mathbf{1 0 0}$ & 4.528 & $\mathbf{1 0 0}$ \\
Mild & 1.538 & $\mathbf{1 0 5}$ & 1.822 & $\mathbf{1 0 1}$ & 1.302 & $\mathbf{1 0 4}$ & 4.661 & $\mathbf{1 0 3}$ \\
Moderate & 1.611 & $\mathbf{1 1 0}$ & 1.838 & $\mathbf{1 0 2}$ & 1.347 & $\mathbf{1 0 7}$ & 4.795 & $\mathbf{1 0 6}$ \\
High & 1.683 & $\mathbf{1 1 5}$ & 1.853 & $\mathbf{1 0 3}$ & 1.392 & $\mathbf{1 1 1}$ & 4.929 & $\mathbf{1 0 9}$ \\
\hline
\end{tabular}

Source: Our data elaboration. $\mathrm{O}=$ average costs incurred by production companies in 2017, in the absence of Xcc; Mild = the company implements defense and prevention systems according to a defined protocol and undergoes a $10 \%$ increase in costs;

Moderate $=$ the company implements defense and prevention systems according to a defined protocol and undergoes a $20 \%$ increase in costs; High = the company implements defense and prevention systems according to a defined protocol and undergoes a $30 \%$ increase in costs.

Table 10. Effects of the adoption of a protocol of prevention from the invasion of Xcc (2018).

the adoption of the protocol was carried out through a partial budget comparing the production costs in the situation before those associated with the new management, assuming that the partial modification of the cultivation techniques does not affect the quantity and quality of the seedlings implemented (Table 10).

\section{Conclusion}

The ornamental Rutaceae feed a substantial commercial flow on an international level, involving the various producing countries of species similar to the Citrus genus, even if, in some of them, the $\mathrm{CBC}$ is present.

The Mediterranean Basin is currently free from the disease, but the relative causative agent $X c c$ is considered to be a quarantine organism for this territory (EU Reg. 2019/2072). The closure of commercial relations from potentially endangered areas is not the tool put in place by EU policy-makers, who, according to the WTO agreements, tend to favor trade by trusting on the functioning of the phytosanitary control systems put in a network.

Given the distance between the Mediterranean basin and the areas in which the bacterium was found (North and South America, Africa, India, and West Asia, and China and East Asia), it is currently unlikely that the path of infection could be the trade of ornamental Rutaceae plants ready for sale. However, the propagation material which has a longer shelf life in the case of transport both within the passenger luggage and with the transport systems used in commercial activities.

So the concrete problem of the introduction of the pathogen exists, and the scientific community is called to evaluate possible damage from invasion to orientate the control policies.

For the determination of the damage caused by the $\mathrm{CBC}$ invasion in the Mediterranean Basin, the relative importance of ornamental Rutaceae was initially extrapolated in the context of the ornamental flowers and plants sector, which is not a smooth operation based on official statistics. 
Therefore, at the micro level, the most likely production and revenue cost were determined per unit of ornamental plant ready for sale, in a representative area and for a species of ornamental Rutaceae widely cultivated (Timpanaro et al., 2018). Finally, with the income method, a value of probable damage has been determined, estimating the change in the profitability of the ornamental citrus nurseries as a result of the application of possible prevention and action guidelines. All this is also in line with the provisions of the recent European phytosanitary legislation (EU Reg. 2016/2031), which focuses a lot of attention on the traceability of the supply chain.

The irreversible damage was estimated according to the loss of income procedure, assuming a period following the eradication of the plants and such as to allow the replanting and restoration of production conditions, equal to 5 years.

The results show that the application of the guidelines entails a significant increase in production costs, in particular, due to the rise in the cost of materials and quotas and other allocations.

Ultimately, such a change in the management of the nursery, aimed at opposing the arrival of Xcc can be implemented only with the introduction of a mechanism to compensate for the effort required by the nursery production companies of ornamental Rutaceae.

In conclusion, the interest of policymakers must be oriented towards a risk of variable invasion according to: type of nursery, with a distinction between a "professional" structure (authorized by the phytosanitary services, also for issuing

Corresponding authors

Professor Giuseppe Timpanaro

Dipartimento di Agricoltura, Alimentazione e Ambiente (Di3A)

University of Catania,

Via S.Sofia, 98-10095123 Catania Italy

Phone: +39095 7580305, E-mail: giuseppe.timpanaro@unict.it

\section{References}

[1] AA. VV. (2012) "Criticità e prospettive delle emergenze fitosanitarie", I Georgofili, Quaderni 2011 - VIII, Edizioni Polistampa, Firenze. EAN: 9788859611660. ISBN 88-596-1166-0. [Online]. Available: http://www.georgofili.net/articoli/scheda/3179 [Accessed: 10 Feb. 2020].

[2] Acquaye, A. K., Alston, J. M., Lee, H. and Sumner, D. A. (2005) "Economic consequences of invasive species policies in the presence of commodity programs: theory and application to citrus canker", Review of Agricultural Economics, Vol. 27, No. 3, pp. 498-504. E-ISSN 2040-5804, ISSN 2040-5790. a passport, which is unlikely to expose itself to any risky imports, to pursue additional profits) and a "hobbyist" structure, which it benefit from the derogation regime and which can be attempted by the possibility of expanding its commercial offer, with imports at risk; type of Rutaceae, with diversity between common and niche ornamental Rutaceae (e.g., Murraya Poncirus trifoliata, Zanthoxylum beecheyanum, Murraya exotica); type of plant material subject to trade (the risk is mainly linked to the propagation material (scions, in particular), easily concealable (in the case of intentional invasion) and potentially able to escape customs controls (especially if placed inside the luggage of apparent tourists); type of trade, distinguishing between traditional and modern forms, represented by multi-channel, electronic and direct distribution formulas for final consumption.

Future research developments will go in the direction of verifying, which market control tool is acceptable for operators and consumers, to counter the invasion of Xcc effectively.

\section{Acknowledgements}

This study was conducted with the financial support of the ORPRAMed Project on "Risk assessment of introduction of Xanthomonas citri subsp. citri through commercial trade of ornamental rutaceous plants in the Mediterranean basin", ERA-NET MNET 2 - Call 2015 (dott.ssa Paola Caruso, per la Ricerca in agricoltura e l'analisi dell'Economia Agraria - CREA, scientific coordinator). paniculata, Citrus mitis, Coleonema pulchrum, 
[3] Allegra, V. and Zarbà, A. S. (2015) "Performance di costi nell'azienda florornamentale: il caso del limone ornamentale in vaso", Italian Review of Agricultural Economics, Vol. 70, No. 3, pp. 271-309. E-ISSN 2281-1559, ISSN 0035-6190. DOI 10.13128/REA-18165. (In Italian).

[4] Ameden, H., Cash, S. B., Vickers, D. A. and Zilberman, D. (2007) "Economics, policy, and border enforcement of invasive species", Editado por Alberta Institute for American Studies. University of Alberta. Edmonton, AB, Canada. [Online]. Available: https://www.researchgate.net/profile/ David_Zilberman/publication/237487893_Economics_Policy_and_Border_Enforcement_of_ Invasive_Species/links/00b4952aebccad36a5000000/Economics-Policy-and-Border-Enforcementof-Invasive-Species.pdf. [Accessed: 15 Feb. 2020].

[5] Anderson, M. and Crosby, M. K. (2018) “An assessment of invasive plants on Shorter University's campus", Mathematical and Computational Forestry \& Natural Resource Sciences, Vol. 10, No. 1, pp. 24-29. ISSN 1946-7664.

[6] Andreu, J. and Vilà, M. (2010) "Risk analysis of potential invasive plants in Spain", Journal for Nature Conservation, Vol. 18, No. 1, pp. 34-44. ISSN 1617-1381. ISSN 1617-1381. DOI 10.1016/j.jnc.2009.02.002.

[7] Atasoy, M. and Çorbac1, Ö. L. (2018) "The Invasive Alien Plants of Turkey A Checklist and Environmental Hazards", J. Appl. Environ. Biol. Sci, Vol. 8, No. 5, pp. 1-8. ISSN 2090-4274.

[8] Bacher, S., Blackburn, T. M., Essl, F., Genovesi, P., Heikkilà, J., Jeschke, J. M., Jones, G., Keller, R., Kenis, M., Kueffer, C., Martinou, A. F., Nentwig, W., Pergl, J., Pysek, P., Rabitsch, W., Richardson, D. M., Roy, H. E., Saul, W. C., Scalera, R., Vilà, M., Wilson J. R. U. and Kumschick S. (2018) "Socio-economic impact classification of alien taxa (SEICAT)", Methods Ecol Evol., Vol. 9, pp. 159-168. E-ISSN 2041-210X. DOI 10.1111/2041-210X.12844.

[9] Barbier, E. B., Gwatipedza, J, Knowler, D. and Reichard S. H. (2011) "The North American horticultural industry and the risk of plant invasion", Agricultural Economics, Vol. 42, pp. 113-130. E-ISSN 1574-0862. DOI 10.1111/j.1574-0862.2011.00556.x.

[10] Basile, F., Foti, V. T. and Timpanaro, G. (2000) "Comparative economic analyses between conventional and eco-compatible cactus pear cultivation in Italy", In IV International Congress on Cactus Pear and Cochineal, ISHS Acta 581, pp. 47-61. E-ISSN 2406-6168, ISSN 0567-7572. DOI 10.17660/ActaHortic.2002.581.2.

[11] Beghin, J. C. and Bureau, J. C. (2001) "Quantitative Policy Analysis of Sanitary, Phytosanitary and Technical Barriers to Trade", Économie international, Vol. 87, p.107-130. ISSN 1240-8093. [Online]. Available: https://www.cairn.info/revue-economie-internationale-2001-3-page-107.htm. [Accessed: 10 Feb. 2020]. DOI 10.17660/ActaHortic.2002.581.2.

[12] Bellard, C., Cassey, P. and Blackburn, T. M. (2016) "Alien taxa as a driver of recent extinctions", Biology Letters, Vol. 12. E-ISSN 1744-957X, ISSN 1744-9561. DOI 10.1098/rsbl.2015.0623.

[13] Bigbsy, H. and Whyte, C. (2001) "Quantifying phytosanitary barriers to trade", In: Hooker, N. and Murano, E. (Eds.) "Interdisciplinary food safety research", CRC Press, Taylor \& Francis Group, LLC. pp. 85-102. E-ISBN 978-1-4200-3909-2.

[14] Born, W., Rauschmayer, F. and Bräuer, I. (2005) "Economic evaluation of biological invasions - A survey”, Ecological Economics, Vol. 55, pp. 321-336. ISSN 0921-8009. DOI 10.1016/j.ecolecon.2005.08.014.

[15] Bradley, B. A., Blumenthal, D. M., Wilcox, D. S. and Ziska, L. H. (2010) "Predicting plant invasions in an era of global change", Trends in Ecology and Evolution, Vol. 25, pp. 310-318. ISSN 0169-5347. DOI 10.1016/j.tree.2009.12.003.

[16] Butti Al Shamsi, K., Compagnoni, A., Timpanaro, G., Cosentino, S. L. and Guarnaccia, P. (2018) "A sustainable organic production model for "food sovereignty" in the United Arab Emirates and Sicily-Italy“, Sustainability, Vol. 10, No. 3. ISSN 1548-7733. DOI 10.3390/su10030620. 
[17] Caruso, P., Licciardello, G., Russo, M.P., Licciardello, C., Caruso, M., Russo, G. and Catara V. (2017) "Il cancro batterico degli agrumi: rischi di introduzione nel Mediterraneo", Rivista di Frutticoltura, Vol. 81, No. 1-2, pp. 40-45. ISSN 0016-2310.

[18] Chapman, D., Purse, B. V., Roy, H. E. and Bullock, J. M. (2017) “Global trade networks determine the distribution of invasive non-native species", Global Ecology and Biogeography, Vol. 26, No. 8, pp. 907-917. E-ISSN 1466-8238. DOI 10.1111/geb.12599.

[19] Costello, C. and McAusland C. (2003) "Protectionism, Trade, and Measures of Damage from Exotic Species Introductions”, American Journal of Agricultural Economics, Vol. 85, No. 4, pp. 964-975. ISSN 0002-9092. DOI 10.1111/1467-8276.00500.

[20] Courtois, P., Figuieres, C., Mulier, C. and Weill, J. (2018) “A cost-benefit approach for prioritizing invasive species", Ecological Economics, Vol. 146, pp. 607-620. ISSN 1873-6106. DOI 10.1016/j.ecolecon.2017.11.037.

[21] Crowley, S. L., Hinchliffe, S. and McDonald, R. A. (2017) "Invasive species management will benefit from social impact assessment", Journal of Applied Ecology, Vol. 54, pp. 351-357. E-ISSN 1365-2664. DOI 10.1111/1365-2664.12817.

[22] Danzì, C., Testa, G., Stella, G., Foti, V. T. and Timpanaro, G. (2020) "Potential and location of an anaerobic digestion plant using prickly pear biomass in semi-arid Mediterranean environment", Journal of Cleaner Production, Vol. 249. ISSN 0959-6526. DOI 10.1016/j.jclepro.2019.119396.

[23] EFSA (European Food Safety Authority). Panel on Plant Health (PLH) (2014) "Scientific Opinion on the risk to plant health of Xanthomonas citri pv. Citri and Xanthomonas citri pv. Aurantifolii for the EU territory", EFSA Journal, Vol. 12, No. 2, 178 p. ISSN 1831-4732. DOI 10.2903/j.efsa.2014.3556.

[24] Evans, E. A. (2003) "Economic dimensions of invasive species”, Choices, Vol. 18. ISSN 0886-5558.

[25] Farnsworth, D., Grogan, K. A., van Bruggen, A. H. and Moss, C. B. (2014) "The potential economic cost and response to greening in Florida citrus", Choices, Vol. 29. ISSN 0886-5558.

[26] Finnoff, D. and Shogren J. F. (2004) "Endogenous Risk as a Tool for Nonindigenous Species Management", Weed Technology, Vol. 18, pp. 1261-1265. E-ISSN 1550-2740. ISSN 0890-037X. DOI 10.1614/0890-037X(2004)018[1261:ERAATF]2.0. $\mathrm{CO} ; 2$.

[27] Finnoff, D. and Tschirhart J. (2003) "Protecting an Endangered Species While Harvesting Its Prey in a General Equilibrium Ecosystem Model", Land Economics , Vol. 79, No. 2, pp. 160-180. E-ISSN 1543-8325, ISSN 0023-7639. DOI 10.2307/3146865.

[28] Finnoff, D. and Tschirhart, J. (2008) "Linking dynamic economic and ecological general equilibrium models", Resource and Energy Economics, Vol. 30, No. 2, pp. 91-114. ISSN 0928-7655. DOI 10.1016/j.reseneeco.2007.08.005.

[29] Finnoff, D. C., Settle, C., Shogren, J. F. and Tschirhart, J. (2006) "Invasive species and the depth of bioeconomic integration", Choices, Vol. 21, pp. 147-152. ISSN 0886-5558.

[30] Finnoff, D., Shogren, J. F., Leung, B. and Lodge, D. (2007) “Take a risk: preferring prevention over control of biological invaders", Ecological Economics, Vol. 62, No. 2, pp. $216-222$. ISSN 0921-8009. DOI 10.1016/j.ecolecon.2006.03.025.

[31] Food and Agricultural Organization. (2001) "The state of food and agriculture 2001", Rome, Italy. [Onlinw]. Available: http:// www.fao.org/docrep/003/x9800e/ x9800e14.htm. [Accessed: 26 May 2020]. ISBN 978-92-5-109873-8. ISSN 0081-4539.

[32] Foti, V. T., Scuderi, A. and Timpanaro, G. (2017) "The Economy of the Common Good: The Expression of a New Sustainable Economic Model", Quality-Access to Success, Vol. 18. E-ISSN 2668-4861, ISSN 1582-2559.

[33] Genovesi, P., Carboneras, C., Vila, M. and Walton, P. (2015) "EU adopts innovative legislation on invasive species: a step towards a global response to biological invasions?”, Biological Invasions, 
Vol. 17, No. 5, pp. 1307-1311. ISSN 1573-1464. DOI 10.1007/s10530-014-0817-8.

[34] Hoffmann, B. D. and Broadhurst, L. M. (2016) "The economic cost of managing invasive species in Australia", NeoBiota, Vol. 31, No. 131, pp. 1-18. E-ISSN 1314-2488, ISSN 1619-0033. DOI 10.3897/neobiota.31.6960.

[35] Horan, R. D., Perrings, C., Lupi, F. and Bulte, E. H. (2002) "Biological pollution prevention strategies under ignorance: the case of invasive species", American Journal of Agricultural Economics, Vol. 84, No. 5, pp. 1303-1310. ISSN 1467-8276. DOI 10.1111/1467-8276.00394.

[36] Horan, R.D. and Lupi F. (2005) "Tradeable risk permits to prevent future introductions of invasive alien species into the Great Lakes”, Ecological Economics, Vol. 52, pp. 289-304. ISSN 0921-8009. DOI 10.1016/j.ecolecon.2004.06.018.

[37] Huang, C. H. (1996) "Effectiveness of Environmental Regulations Under Imperfect Enforcement and the Firm's Avoidance Behavior”, Environmental and Resource Economics, Vol. 8, pp. 183-204. E-ISSN 1573-1502, ISSN 0924-6460. DOI 10.1007/BF00357363.

[38] Jardine, S. L. and Sanchirico, J. N. (2018) "Estimating the cost of invasive species control", Journal of Environmental Economics and Management, Vol. 87, pp. 242-257. ISSN 0095-0696. DOI 10.1016/j.jeem.2017.07.004.

[39] Jenkins, P. T. (2002) "Paying for protection from invasive species", Issues in Science and Technology, Vol. 19, pp. 67-72. ISSN 0748-5492.

[40] Jeschke, J. M., Bacher, S., Blackburn, T. M., Dick, J. T. A., Essl, F., Evans, T., Gaertner, M., Hulme, P. E., Kühn, I., Mrugała, A., Pergl, J., Pyšek, P., Rabitsch, W., Ricciardi, A., Richardson, D. M., Sendek, A., Vilà, M., Winter, M. and Kumschick, S. (2014) "Defining the Impact of Non-Native Species”, Conservation Biology, Vol. 28, pp. 1188-1194. ISSN 1523-1739. DOI 10.1111/cobi.12299.

[41] Kadambe, S. and Segerson K. (1998) "On the Role of Fines as an Environmental Tool", Journal of Environmental Planning, Vol. 41, No. 2, pp. 217-26. E-ISSN 1360-0559, ISSN 0964-0568. DOI 10.1080/09640569811722.

[42] Kambhu, J. (1990) "Direct Controls and Incentives Systems of Regulation", Journal of Environmental Economics and Management, Vol. 18, pp. 72-85. ISSN 0095-0696. ISSN 0095-0696. DOI 10.1016/0095-0696(90)90040-6.

[43] Knowler, D. and Barbier, E. B. (2005) "Importing exotic plants and the risk of invasion: Are market based instruments adequate?", Ecological Economics, Vol. 52, pp. 341-354. ISSN 0921-8009. DOI 10.1016/j.ecolecon.2004.06.019.

[44] Leung, B., Lodge, D. M., Finnoff, D., Shogren, J. F., Lewis, M. A. and Lamberti, G. (2002) "An ounce of prevention or a pound of cure: bioeconomic risk analysis of invasive species", Proceedings of the Royal Society of London. Series B: Biological Sciences, Vol. 269, pp. 2407-2413. ISSN 1471-2954. DOI 10.1098/rspb.2002.2179.

[45] McAusland, C. and Costello C. (2004) "Avoiding invasives: trade related polices for controlling unintentional exotic species introductions", Journal of Environmental Economics and Management, Vol. 48, pp. 954-977. ISSN 0095-0696. DOI 10.1016/j.jeem.2003.11.002.

[46] Moss, C. B., Grogan, K. A., Farnsworth, D. and van Bruggen, A. H. C. (2015) “The economic cost of huanglongbing (citrus greening) to Florida's orange industry: estimates of producer and consumer surplus", UF Food Resources and Economics Department. [Online]. Available: http://www. imok. ufl. edu/hlb/database/pdf/10V_Moss_14.pdf. [Accessed: 20 May, 2020].

[47] Oh, Y. (1995) "Surveillance or Punishment? A Second-Best Theory of Pollution Regulation", International Economic Journal, Vol. 9, No. 3, pp. 89-101. E-ISSN 1743-517X, ISSN 1016-8737. DOI 10.1080/10168739500000023.

[48] Panetta, F. and Gooden, B. (2017) "Managing for biodiversity: Impact and action thresholds for invasive plants in natural ecosystems", NeoBiota, Vol. 34, pp. 53-66. E-ISSN 1314-2488, 
ISSN 1619-0033. DOI 10.3897/neobiota.34.11821.

[49] Perrings, C. (2001) "The economics of biological invasions", Land Use and Water Resources Research, University of Newcastle upon Tyne, Centre for Land Use and Water Resources Research, Vol. 1, pp. 1-9. DOI 10.22004/ag.econ.47851.

[50] Scuderi, A. and Sturiale, L. (2016) "Multi-criteria evaluation model to face phytosanitary emergencies: The case of citrus fruits farming in Italy", Agricultural Economics, Vol. 62, No. 5, pp. 205-214. E-ISSN 1805-9295, ISSN 0139-570X. DOI 10.17221/114/2015-AGRICECON.

[51] See, L. and Dwight, R. (1984) "The Economics of Enforcing Pollution Taxation", Journal of Environmental Economics and Management, Vol. 11, No. 2, pp. 147-64. ISSN 0095-0696. DOI 10.1016/0095-0696(84)90013-5.

[52] Shogren, J. F., Finnoff, D., McIntosh, C. and Settle, C. (2016) "Integration-valuation nexus in invasive species policy", Agricultural and Resource Economics Review, Vol. 35, No. 1, pp. 11-20. E-ISSN 2372-2614, ISSN 1068-2805. DOI 10.1017/S1068280500010017.

[53] Shogren, J. F. and Crocker T. D. (1991) "Risk, self-protection, and ex ante economic value", Journal of Environmental Economics and Management, Vol. 20, No. 1, pp. 1-15. ISSN 0095-0696. DOI 10.1016/0095-0696(91)90019-F.

[54] Soliman, T., Mourits, M. C. M., Lansink, A. O. and Van der Werf, W. (2010) "Economic impact assessment in pest risk analysis", Crop Protection, Vol. 29, No. 6, pp. 517-524. ISSN 0261-2194. DOI 10.1016/j.cropro.2009.12.014.

[55] Soliman, T., Mourits, M. C. M., Oude Lansink, A. G. J. M. and van der Werf V. (2013) "Economic justification for quarantine status - the case study of 'Candidatus Liberibacter solanacearum' in the European Union”, British Society for Plant Pathology, Vol. 62, pp. 1106-1113. E-ISSN 1365-3059. DOI 10.1111/ppa.12026.

[56] Timpanaro, G., Foti, V. T. and Spampinato, D. (2013) "Organic Farming in Sicily: analysis and perspectives through the main Productive Chains”, Calitatea, Vol. 14, No. 157. E-ISSN 26684861. ISSN 1582-2559.

[57] Timpanaro, G., Scuderi, A. and Foti, V. T. (2014) "A network for the conservation of agrobiodiversity of local ecotypes“, In: VI Balkan Symposium on Vegetables and Potatoes 1142. Acta Horticulture, pp. 163-170. ISBN 978-94-62611-30-6. ISSN 0567-7572, E-ISSN 2406-6168. DOI 10.17660/ActaHortic.2016.1142.26.

[58] Timpanaro, G., Urso, A. and Foti, V. T. (2018) "Technical and scale efficiency in nursery enterprises in an area of significant widespread horticulture in Italy", HortScience, Vol. 53, No. 2, pp. 208-216. E- ISSN 2327-9834, ISSN 0018-5345. DOI 10.21273/HORTSCI12344-17.

[59] Timpanaro, G., Cammarata, M. and Urso, A. (2020) "Analysis of Trade Flows of Ornamental Citrus Fruits and Other Rutaceae in the Mediterranean Basin and Potential for Xantomonas citri Introduction", Agriculture, Vol. 10, No. 5, 171 p. ISSN 2077-0472. DOI 10.3390/agriculture10050171.

[60] Williams, F., Eschen, R., Harris, A., Djeddour, D., Pratt, C., Shaw, R. S., Varia, S., LamontagneGodwin, J., Thomas, S. E. and Murphy, S. T. (2010) "The economic cost of invasive non-native species on Great Britain”, CABI Proj No VM10066, 1-99. CABI Head Office, Nosworthy Way, Wallingford OX10 8DE, UK. 